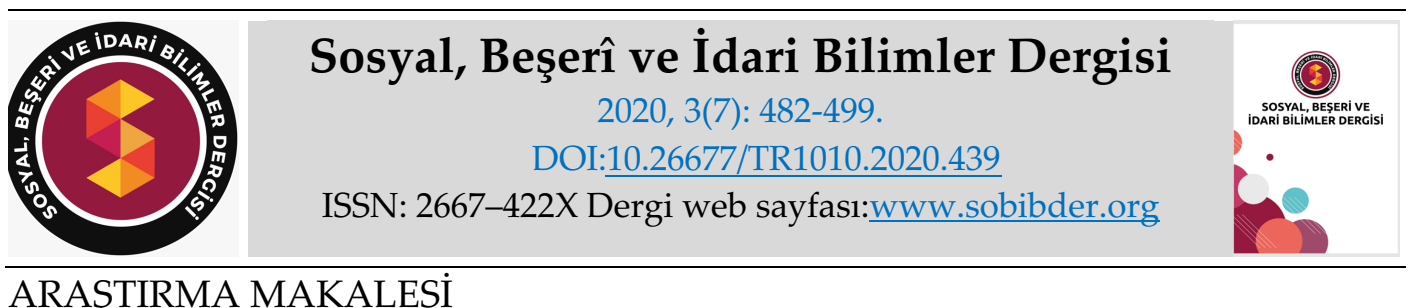

ARAȘTIRMA MAKALESI

\title{
5-6 Yaş Grubu Çocukların Ebeveynleriyle İlişkilerinin İncelenmesi*
}

Uzm. Çocuk Gelişimci Merve SOLAK ARABACI, Aile, Çalışma ve Sosyal Hizmetler İl Müdürlügü, Manisa, e-posta: mervesolak@hacettepe.edu.tr ORCID: https://orcid.org/0000-0003-2818-9418

Doç. Dr. Haktan DEMİRCiOĞLU, Hacettepe Üniversitesi, Sağlık Bilimleri Fakültesi, Ankara, eposta: hdemircioglu@hacettepe.edu.tr ORCID: https://orcid.org/0000-0002-5092-1698

Öz

Araştırmada 5-6 yaş grubu çocukların ebeveynleriyle ilişkilerinin demografik değişkenlere göre incelenmesi amaçlanmıştır. Araştırmanın örneklemini, Manisa İlinin Yunusemre ve Şehzadeler ilçelerinde bulunan bağımsız anaokullarına devam eden 5-6 yaş grubu 504 çocuk ve bu çocukların ebeveynleri (496 anne, 306 baba) oluşturmuştur. Araştırma, nicel araştırma yöntemlerinden tarama modeline göre tasarlanmıştır. Verilerin elde edilmesinde "Çocuk Ana-Baba İlişki Ölçeği" ile araştırmacılar tarafından geliştirilen "Genel Bilgi Formu" kullanılmıştır. Araştırmada elde edilen verilerin analizinde Bağımsız Gruplar t Testi, Mann Whitney-U Testi, Kruskal Wallis-H Testi, Tek Yönlü Varyans Analizi (ANOVA) kullanılmıştır. Araştırma bulguları incelendiğinde anne ile çocuk arasındaki çatışmalı ilişkinin çocuğun cinsiyetine, öğrenim durumuna ve aile gelir durumuna göre; baba ile çocuk arasındaki ilişkilerin çocuğun cinsiyetine göre, baba ile çocuk arasındaki çatışmalı ilişkinin çocuğun yaşına göre anlamlı düzeyde farklılık gösterdiği sonucuna ulaşılmıştır. Araştırma bulguları ilgili literatür çerçevesinde tartışılarak yorumlanmış ve önerilerde bulunulmuştur.

*Bu çalışma Doç. Dr. Haktan Demircioğlu'nun danışmanlığında Merve Solak Arabacı'nın Hacettepe Üniversitesi Sağlık Bilimleri Enstitüsü'nde hazırladığı “5-6 Yaş Grubu Çocukların Ebeveynleri ve Akranlarıyla İlişkileri ile Ebeveynlerinin Evlilik Yaşam Doyumlarının İncelenmesi" isimli yüksek lisans tezinin bir kısmından üretilmiştir.

Anahtar Kelimeler: Ebeveyn-Çocuk İlişkileri, Ana-Baba-Çocuk, Olumlu İlişki, Çatışmalı İlişki, Okul Öncesi Dönem.

Makale Gönderme Tarihi: 27.03.2020

Makale Kabul Tarihi: 01.07.2020

\section{Önerilen Atıf:}

Solak Arabacı, M. ve Demircioğlu, H. (2020). 5-6 Yaş Grubu Çocukların Ebeveynleriyle İlişkilerinin İncelenmesi, Sosyal, Beşeri ve İdari Bilimler Dergisi, 3(7): 482-499.

(c) 2020 Sosyal, Beşerî ve İdari Bilimler Dergisi. 


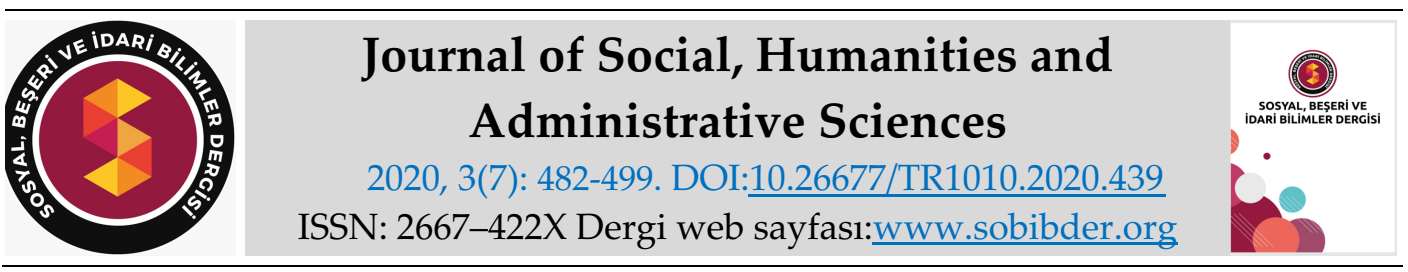

\title{
RESEARCH PAPER
}

\section{Examination of 5-6 Age Group Children's Parent Relationships}

Merve SOLAK ARABACI, Expert Child Developers, Provincial Directorate of Family, Labor and Social Services, Manisa, e-mail: mervesolak@hacettepe.edu.tr ORCID: https://orcid.org/0000-0003-2818-9418

Doç. Dr. Haktan DEMIRCiOĞLU, Hacettepe University, Faculty of Health Sciences, Ankara, email: hdemircioglu@hacettepe.edu.tr

ORCID: https://orcid.org/0000-0002-5092-1698

\begin{abstract}
Purpose of the research is to examine the 5-6 age group children's parent relationships in terms of some demographic variables. The sample of the study selected by simple random sampling method, consisted of 504 children between the ages of 5-6 who attend formal and private independent kindergartens located in Yunusemre and Şehzadeler counties of Manisa and their parents (496 mothers, 306 father). In this study "The General Information Form" and "Child Parent Relationship Scale" were used. In the study, Independent Groups t-Test, Mann-Whitney U Test, One Way Anova, Kruskal Wallis-H Test were used to analyze of data. According to the results of this study, significant differences were found between scores of children's conflicting relationship with mother, and gender of children; between scores of children's relationships with mother, and mother's level of education and monthly income of family. The findings of the study were discussed, interpreted and appropriate suggestions were given within the scope of the literature.
\end{abstract}

Keywords: Child- Parent Relationship, Mother-Father-Children, Positive Relation, Conflicting Relation, Preschool Period.

Received: 27.03 .2020

Accepted: 01.07.2020

\section{Suggested Citation:}

Solak Arabacı, M. and Demircioğlu, H. (2020). Examination of 5-6 Age Group Children's Parent Relationships, Journal of Social, Humanities and Administrative Sciences, 3(7): 482-499.

(c) 2020 Sosyal, Beşerî ve İdari Bilimler Dergisi. 


\section{GİRIŞ}

Bir bebeğin ailesiyle etkileşimi henüz doğum öncesi dönemde başlamaktadır. Öyle ki anne babanın bebek sahibi olmak isteyip istememesi, bebek sahibi olmaya hazır bulunup bulunmaması, dünyaya gelecek bebekten beklentileri, bebeğin hayata dair ilk izlenimlerinde ve çevresi ile kuracağı etkileşimde önemli bir yere sahiptir (Kandır ve Alpan, 2008). Yapılan çalışmalar, planlanan gebeliklerde ebeveyn- çocuk bağlanmasının planlanmayan gebeliklere göre anlamlı düzeyde yüksek olduğu sonucunu ortaya koymaktadır (Üstünöz ve arkadaşları, 2010; Camarneiro ve arkadaşları, 2017).

Bebeğin doğumuyla beraber ebeveyn çocuk arasındaki etkileşim devam etmekte ve bebeğin ilk sosyal ilişki ağı oluşmaktadır. Yeni doğan bebeğin sosyal ilişkisi ağlama ile başlamakta, buna zamanla gülme ile konuşma eklenmekte ve bebeğin kurduğu iletişim yolları giderek zenginleşmektedir. Ebeveynlerinin ve etrafındaki diğer insanların uyarılarına çeşitli tepkiler veren bebek, bu süreçte taklit yoluyla öğrenmeye başlamaktadır. Dolayısıyla çocuğun kendini kontrol etme ve sosyal ilişkilerini yönetme becerilerini kazanmasında ebeveynler büyük rol oynamaktadır (Çiftçi Topaloğlu, 2013). Anne ve babasının davranışlarını model alan çocuk, kabul gören ve görmeyen davranışları onlardan öğrenerek davranışlarını bu yönde şekillendirmektedir (Yavuzer, 2016).

Bireyin tüm yaşamı boyunca sosyal duygusal gelişimini etkileyen unsurların başında yaşamın ilk yıllarında özellikle anneyle veya çocuğa temel bakım veren ile kurulan bağlanma ilişkisi gelmektedir. Yaşamın ilk yılında oluşturulan bağlanma tarzının hem okul öncesi dönemde hem de sonrasında kişinin duygusal yapısı ve sosyal ilişkileri üzerindeki rolü oldukça önemlidir (Yaşar, 2015). Öyle ki bağlanma teorisi, erken dönemde kurulan çocuk-ebeveyn bağı güvenliğinin, çocuğun ömrü boyunca kişilerarası ilişkilerine yansıdığını belirtmektedir (Schneider ve arkadaşları, 2001). Benzer şekilde psikanalitik kurumlar da bireyi odak noktası alarak ilişkilerin önemini vurgulamakta ve önceki ilişkilerin sonraki ilişkileri etkilediğini savunmaktadır (Hortaçsu, 2012). Yörükoğlu (2000) ebeveyn çocuk ilişkisinin, çocukların dünyayı ya güvenli, yaşamaya değer ya da korkulacak, güvensiz bir yer olarak algılamalarına neden olduğunu belirtmektedir. Yani ebeveynlerin çocuk ile sosyal çevre arasında bir köprü misyonu üstlendiği söylenebilir.

Freud, kişilik gelişiminde özellikle ilk altı yılın çok önemli olduğunu vurgulamakta ve bu zaman diliminde çocuğun başından geçen her türlü yaşantının kümülatif olarak onun sosyal-duygusal gelişimini şekillendiren birer unsur olduğunu belirtmektedir (Trawick Smith, 2014). Yapılan çalışmalar çocuğun ebeveynleri ile arasındaki olumlu ve sıcak ilişkilerin çocuğun sosyal duygusal gelişimini desteklediğini (Paley ve arkadaşları, 2000; Eisenberg ve arkadaşları, 2001; Zhang, 2011) diğer yandan olumsuz ilişkilerin ise çocuğun sosyal duygusal gelişimini olumsuz yönde etkilediğini (Laibe ve arkadaşları, 2002) göstermektedir.

Anne, baba ve çocuk arasındaki iletişimin sağlıklı ve etkili olabilmesi için ebeveynlerin kendilerine güvenli, birbirlerine ve çocuklarına karşı saygıll, çocuklarının sorunlarına duyarlı, işbirlikçi, çocukların duygu ve düşüncelerini ifade etmesine firsat veren ve kabul edici bir tutuma sahip olmaları gerekmektedir. İnatçı bir tutumla kendi düşüncelerini savunarak kendi görüş ve düşünceleri dışındaki doğruları kabul etmek istemeyen, çocuklarının görüş ve düşüncelerini önemsemeyen anne-babaların çocuklarıyla sağlıklı iletişim kurmaları mümkün olmamaktadır (Çă̆daş, 2009).

Büyüme aşamalarında başarılı olan çocuklar, iyi aile ilişkileri içinde yetişmiş bireylerdir. Aile içinde kurulan başarılı ilişkiler mutlu, arkadaşça, bunalımdan uzak ve yapıcı bireylerin oluşumunu sağlar. Aksi durumda, uyum bozuklu gösteren çocuklar, genellikle başarısız bir anne-baba-çocuk ilişkisinin ürünüdür. Anne ve babanın, sevgi ve ilgisinden yoksun olarak büyüyen çocuklar, bir takım davranış ve uyum bozuklukları gösterebilir (Yavuzer, 2014). Literatürde destekleyici 
ebeveynliğin çocuğun dışsallaştırma sorunları ile negatif yönde ilişkili olduğunu (Spinrad ve arkadaşları, 2007); anne ile çocuk arasındaki çatışmalı ilişki arttıkça çocuğun dışa yönelim davranış problemlerinin arttığını (Yüksek Usta, 2014); katı ebeveyn tutumlarının çocuğun saldırgan davranışları ile ilişkili olduğunu (Kimonis ve arkadaşları, 2006) gösteren araştırmalar bulunmaktadır.

Ebeveynlerin çocukları ile kurdukları ilişkilerde önemli bir etkiye sahip olduğunu gösteren pek çok çalışma bulunmaktadır (Erel ve Burman, 1995; Fishman ve Meyers, 2000; Saygı, 2011; Yüksek Usta, 2014). Ancak, çocuklar da çevresel uyaranların pasif alıcısı değildir. Çocukların özellikleri de çevresindekilerle kurdukları ilişkileri etkilemektedir (Şendil, 2014). Dolayısıyla ebeveyn çocuk ilişkilerinde de sadece ebeveynlerin belirleyici olmadığı söylenebilir. Ebeveyn ve çocuk ilişkilerinin işlenişi yıllar içerisinde değişiklik göstermiştir. Çalışmalar ilk yıllarda ebeveynden çocuğa tek yönlü bir etki varsayımından yola çıkarken, sonraki yıllarda çocukların gelişen beceri ve özelliklerinin de ebeveyn çocuk ilişkilerini etkilediği görüşü önem kazanmış ve böylece ebeveyn çocuk ilişkisi çift yönlü bir ilişki olarak düşünülmeye başlanmıştır (Hortaçsu, 2003).

Çocuğun sosyal duygusal yönden sağlıklı, uyumlu bir birey olabilmesinde bu kadar büyük öneme sahip olduğu bilinen ebeveyn çocuk ilişkilerinin incelenmesinin, ilişkiyi etkileyen faktörlerin belirlenmesinin, ilişkinin yapısının ortaya konulmasının önemli olduğu düşünülmektedir. Literatürde ebeveyn ve çocuk ilişkilerine yönelik çalışmalar bulunmakla birlikte Tayan ve arkadaşları (2019), 2003-2017 yılları arasında ebeveyn çocuk ilişkilerini araştıran makaleleri inceledikleri tematik içerik analizi çalışmalarında, araştırmaların \%6,2' sinin sosyo-demografik unsurları ele aldığını belirtmiştir. Buradan yola çıkarak araştırmada, en yakın sosyal çevresi aile olan 5-6 yaş grubu çocukların ebeveynleriyle ilişkilerinin hem çocuğa yönelik hem de ebeveyne yönelik bazı sosyo-demografik değişkenler açısından incelenmesi amaçlanmıştır. Bu amaç doğrultusunda araştırmada aşağıdaki sorulara cevap aranmıştır:

- 5-6 yaş grubu çocukların ebeveynleriyle ilişkileri çocuğun cinsiyetine, yaşına göre anlamlı bir farklıllk göstermekte midir?

- 5-6 yaş grubu çocukların ebeveynleriyle ilişkileri anne-babanın yaşına, öğrenim durumuna, ailenin gelir durumuna göre anlamlı bir farklılık göstermekte midir?

\section{YÖNTEM}

\section{Araştırmanın Türü}

Araştırmada nicel araştırma yöntemlerinden biri olan tarama modeli kullanılmıştır. Tarama modeli, geçmişte ya da halen var olan bir durumu olduğu gibi betimlemeyi amaçlayan araştırma yaklaşımıdır (Karasar, 2014). Bu kapsamda araştırmada çocuk ile ebeveynleri arasındaki olumlu ve çatışmalı ilişkiler, ele alınan demografik değişkenler açısından incelenmiştir.

\section{Çalışma Grubu}

Manisa'nın Şehzadeler İlçesinde dördü resmi biri özel olmak üzere beş bağımsız anaokulu; Yunusemre İlçesinde ise 7'si resmi, 14'ü özel olmak üzere 21 bağımsız anaokulu bulunduğu; mevcut 26 anaokulunda ise 5-6 yaş grubunda kayıtlı toplamda 1125 çocuk olduğu tespit edilmiştir. $\mathrm{Bu}$ çerçevede araştırmanın evreni 1125 çocuk ve ebeveynleri olarak belirlenmiştir.

Araştırmanın örneklemi belirlenirken basit seçkisiz örnekleme yöntemi kullanılmıştır. Örneklemin evreni temsiliyet gücünü arttırmak amacıyla, evrende bulunan tüm anaokullarından veri toplanması hedeflenmiştir. Araştırmanın örneklemini Manisa İlinin Yunusemre ve Şehzadeler ilçelerinde bulunan ve araştırmaya katılmayı kabul eden dokuzu özel bağımsız anaokulu, 10'u 
resmi bağımsız anaokulu olmak üzere toplam 19 bağımsız anaokulunda kayıtlı 504 çocuk ve bu çocukların ebeveynleri (496 anne, 306 baba) oluşturmuştur.

\section{Veri Toplama Araçları}

\section{Genel Bilgi Formu}

Araştırmaya katılan çocuklar, anneleri ve babaları hakkında bilgi toplamak amacıyla araştırmacı tarafından hazırlanmıştır. Genel bilgi formu, çocukların yaş ve cinsiyetlerine; anne ve babaların ise yaş, öğrenim durumu ve ailenin gelir durumuna ilişkin bilgilerin belirlenmesine yönelik soruları içermektedir. Genel bilgi formunun üst bölümünde çalışmanın amacına ilişkin bilgi yer almaktadır.

\section{Çocuk Ana-Baba İlişki Ölçeği}

Akgün ve Yeşilyaprak (2010)'nn belirttiğine göre ölçek anne, baba ve çocuk arasındaki ilişkiyi belirlemek amacıyla 1992 yılında Pianta tarafından geliştirilmiştir. Ölçeğin orjinali üç alt boyuttan oluşmakta olup çatışma alt boyutu 14 madde, bağlanma alt boyutu 6 madde ve olumlu ilişki alt boyutu 10 madde olmak üzere ölçek, toplam 30 maddeden oluşmaktadır (Akgün ve Yeşilyaprak, 2010).

Ölçeğin Türkçe'ye uyarlama çalışması 2010 yılında Akgün ve Yeşilyaprak (2010) tarafından yapılmıştır. Uyarlama çalışmaları sırasında orijinal ölçekten 6 madde çıkarılmış ve ölçeğin Türkçe formu 24 maddeden oluşturulmuştur. Ölçeğin Türkçe'ye uyarlanmış hali, çatışma ve olumlu ilişki olmak üzere 2 alt boyuttan oluşmaktadır. Ölçek 5'li likert tipindedir. Ölçekte olumlu ve olumsuz ifadeler yer almakta olup ölçekteki olumlu ifadeler tersine çevrilerek puanlanmaktadır. Ölçekten yüksek puan almak olumsuz ilişkiyi, düşük puan almak ise olumlu ilişkiyi göstermektedir. Ölçekten alınabilecek en yüksek toplam puan 120 iken en düşük toplam puan ise 24 tür. Ölçeğin çatışma alt boyutunda yer alan maddelerin yük değeri .38 ile .72 arasında değişmektedir. Aynı değerler olumlu ilişki alt boyutu için $.42-.72$ arasındadır. Ölçeğin test tekrar test güvenirlik katsayısı çatışma alt boyutu için .98 , olumlu ilişki alt boyutu için .96 ve toplam puan için .96 bulunmuştur. Ölçeğin güvenirliği ile ilgili olarak alt boyutlara ilişkin iç tutarlık katsayıları çatışma alt boyutu için .85 , olumlu ilişki alt boyutu için .73 ve toplam puan için ise .73 olarak bulunmuştur. Spearman Brown düzeltmesinden sonra testin iki yarısı arası korelasyonu ise aynı sırayla .84, .73 ve .72'dir (Akgün ve Yeşilyaprak, 2010).

\section{Veri Toplama İşlemi}

Çocuk Ana-Baba İlişki Ölçeği'nin, araştırmada kullanılabilmesi için ölçeğin uyarlama çalışmasını yapan araştırmacı ile iletişime geçilerek gerekli izin alınmıştır. Ardından Manisa İl Milli Eğitim Müdürlüğü'nden ve Hacettepe Üniversitesi Etik Komisyonu'ndan gerekli izinler alınarak çalışma yürütülmüştür. Genel Bilgi Formu ve araştırmada kullanılan ölçek, bağımsız anaokulları aracılığı ile ebeveynlere ulaştırılmış ve ebeveynlerden dönen veri toplama araçları araştırmacı tarafından anaokullarından alınmıştır.

\section{Veri Analizi}

Araştırmada elde edilen veriler SPSS 20.00 paket programı kullanılarak analiz edilmiştir. Normal dağılım gösteren verilerin analizinde Bağımsız Gruplar için T Testi, Tek Yönlü Varyans Analizi (ANOVA) kullanılmış olup normal dağılım göstermeyen verilerin analizinde ise Mann WhitneyU Testi, Kruskal Wallis-H Testi kullanılmıştır. Verilerin dağılımı değerlendirilirken histogram, P$\mathrm{P}, \mathrm{Q}-\mathrm{Q}$ grafikleri ile çarpıklık (kurtosis) ve basıklık (skewness) değerleri dikkate alınmışır (Field, 
2009). Çalışmada çarpıklık ve basıklık ölçülerinin $\pm 1,5$ sınırları içerisinde olması, normal dağılımın varlığına kanıt olarak değerlendirilmiştir (Tabachnick ve Fidell, 2013). Veri dağılımı incelendiğinde baba yaş değişkeninde yer alan "25 yaş ve altı" ve "26-30 yaş" kategorilerindeki baba sayılarının yapılacak analiz için yeterli olmaması nedeniyle söz konusu kategoriler birleştirilerek "30 yaş ve altı" kategorisi oluşturulmuştur.

\section{BULGULAR}

Araştırmaya ilişkin bulgular aşağıda sunulmuştur. Tablo 1 de sunulan demografik dağılımlar, örneklemde yer alan 504 çocuk referans alınarak hazırlanmıştır.

Tablo 1. Araştırmaya Katılan Çocuklara ve Ebeveynlerine İlişkin Demografik Özelliklerin Dağılımı

\begin{tabular}{|c|c|c|c|c|}
\hline & Değişkenler & Gruplar & $\mathbf{F}$ & $\%$ \\
\hline \multirow{4}{*}{ Çocuk } & \multirow{2}{*}{ Cinsiyet } & $\mathrm{K} 1 \mathrm{z}$ & 237 & 47 \\
\hline & & Erkek & 267 & 53 \\
\hline & \multirow{2}{*}{ Yaş } & 60-65 Ay & 237 & 47 \\
\hline & & 66-72 Ay & 267 & 53 \\
\hline \multirow{8}{*}{ Anne } & \multirow{5}{*}{ Yaş } & 25 yaş ve altı & 26 & 5,2 \\
\hline & & $26-30$ yaş arası & 126 & 25 \\
\hline & & $31-35$ yaş arası & 207 & 41,1 \\
\hline & & 36- 40 yaş arası & 122 & 24,2 \\
\hline & & 41 yaş ve üzeri & 23 & 4,6 \\
\hline & \multirow{3}{*}{ Öğrenim Durumu } & İlköğretim ve öncesi & 133 & 26,4 \\
\hline & & Ortaöğretim & 192 & 38,1 \\
\hline & & Yükseköğretim & 179 & 35,5 \\
\hline \multirow{7}{*}{ Baba } & \multirow{4}{*}{ Yaş } & 30 yaş ve altı & 52 & 10,3 \\
\hline & & 31- 35 yaş arası & 184 & 36,5 \\
\hline & & 36- 40 yaş arası & 173 & 34,3 \\
\hline & & 41 yaş ve üzeri & 95 & 18,8 \\
\hline & \multirow[t]{3}{*}{ Öğrenim Durumu } & İlköğretim ve öncesi & 136 & 27 \\
\hline & & Ortaöğretim & 170 & 33,7 \\
\hline & & Yükseköğrenim & 198 & 39,3 \\
\hline \multirow{5}{*}{ Aile } & \multirow{5}{*}{$\begin{array}{l}\text { Aylık Ortalama Gelir } \\
\text { Durumu }\end{array}$} & 1.500 TL ve altı & 76 & 15,1 \\
\hline & & $1.501 \mathrm{TL}-3.000 \mathrm{TL}$ & 196 & 38,9 \\
\hline & & $3.001 \mathrm{TL}-4.500 \mathrm{TL}$ & 135 & 26,8 \\
\hline & & 4.500 TL ve üstü & 97 & 19,2 \\
\hline & & Toplam & 504 & 100 \\
\hline
\end{tabular}

Tablo 1 incelendiğinde örneklemi oluşturan çocukların $\% 47^{\prime} \operatorname{sinin}$ kız, \%53'ünün erkek olduğu görülmektedir. Örneklem grubundaki çocukların \%47'si 60-65 aylıkken \%53'ü 66-72 aylıktır. Çocukların ebeveynlerine ilişkin dağılımlar incelendiğinde annelerinin $\% 5,2$ sinin 25 yaş ve altında, \%25'inin 26-30 yaşında, \%41,1'inin 31-35 yaşında, \%24,2' sinin 36-40 yaşında, \%4,6'sının ise 41 yaş ve üzerinde olduğu görülmektedir. Çocukların annelerinin öğrenim durumu; \%26,4'ü "İlköğretim ve öncesi", \%38,1'i “Ortaöğretim", \%35,5'i "Yükseköğretim" olarak dağılım göstermektedir. Çocukların annelerinin \%44,2'si çalışırken, \%55,8'i çalışmamaktadır. Çocukların babalarının \%10,3'ü 30 yaş ve altında, \%36,5'i 31-35 yaş arasında, \%34,3'ü 36-40 yaş arasında, $\% 18,8$ 'i 41 yaş ve üzerindedir. Babaların öğrenim durumuna ilişkin bulgular incelendiğinde 
babaların \%27'sinin "Illköğretim", \%33,7'sinin "Ortaöğretim" ve \%39,3'ünün "Yükseköğretim" mezunu olduğu görülmektedir. Aylık ortalama gelirinin ailelerin \%15,1'inde "1.500 TL ve altında", \%38,9'unda "1.501-3.000 TL arasinda", \%26,8'inde "3.001-4.500 TL arasinda", \%19,2'sinde "4.501 TL ve üzeri" olduğu görülmektedir.

Tablo 2.1. Çocuk Ana-Baba İlişki Ölçeğinin Alt Boyut Puanlarının Cinsiyete Göre T Testi Sonuçları

\begin{tabular}{cccccccccc}
\hline $\begin{array}{c}\text { ÇABíÖ } \\
\text { Alt Boyutları }\end{array}$ & Cinsiyet & $\mathbf{n}$ & $\overline{\mathbf{X}}$ & Ortanca & Min & Max & ss & $\mathbf{t}$ & $\mathbf{p}$ \\
\hline Ana-Çocuk & Kiz & 233 & 15,06 & 14 & 10 & 25 & 3,38 & $-1,536$ &, 125 \\
Olumlu İlişki & Erkek & 263 & 15,56 & 15 & 10 & 25 & 3,90 & & \\
\hline Baba-Çocuk & Kiz & 145 & 14,66 & 14 & 10 & 26 & 3,52 & $-3,785$ &, $000^{*}$ \\
Olumlu İlişki & Erkek & 161 & 16,40 & 16 & 10 & 29 & 4,48 & & \\
\hline
\end{tabular}

${ }^{*} \mathrm{p}<0,05$

Tablo 2.1 incelendiğinde örneklem grubunun Çocuk Ana-Baba İlişki Ölçeğinin ana-çocuk olumlu ilişki alt boyutundan almış oldukları puanların çocuğun cinsiyetine göre anlamlı bir farklılık göstermediği $(p>0,05)$, baba-çocuk olumlu ilişki alt boyutundan almış oldukları puanların ise çocuğun cinsiyetine göre anlamlı düzeyde farklılaştığı görülmektedir $(\mathrm{p}<0,05)$. Bu bulgu üzerinden kız çocukların babalarıyla ilişkilerinin erkek çocuklara göre daha olumlu olduğu söylenebilir.

Tablo 2.2. Çocuk Ana-Baba İlişki Ölçeğinin Alt Boyut Puanlarının Cinsiyete Göre Mann-Whitney U Testi Sonuçları

\begin{tabular}{ccccccccccc}
\hline $\begin{array}{c}\text { ÇABíÖ } \\
\text { Alt Boyutları }\end{array}$ & Cinsiyet & $\mathbf{n}$ & $\overline{\mathbf{X}}$ & Ortanca & Min & Max & ss & $\begin{array}{c}\text { Sıra } \\
\text { Ortalaması }\end{array}$ & z & p \\
\hline Ana-Çocuk & Kız & 233 & 29,14 & 27 & 14 & 61 & 9,49 & 234,42 & $-2,061$ & \multirow{2}{*}{$\mathbf{0 3 9 ^ { * }}$} \\
Çatışmalı İlişki & Erkek & 263 & 30,66 & 30 & 15 & 54 & 8,46 & 260,98 & & \\
\hline Baba-Çocuk & Kız & 145 & 26,61 & 24 & 14 & 56 & 8,13 & 133,85 & \multirow{2}{*}{$-3,690$} & \multirow{2}{*}{$\mathbf{0 0 0 ^ { * }}$} \\
Çatışmalı İlişki & Erkek & 161 & 29,9 & 30 & 14 & 53 & 8,19 & 171,2 & & \\
\hline
\end{tabular}

${ }^{*} \mathrm{p}<0,05$

Tablo 2.2 incelendiğinde örneklem grubunun Çocuk Ana-Baba İlişki Ölçeğinin ana-çocuk çatışmalı ilişki ve baba-çocuk çatışmalı ilişki alt boyutlarından almış oldukları puanların çocuğun cinsiyetine göre anlamlı düzeyde farklılaştığı görülmektedir $(p<0,05)$. Bu bulgu üzerinden erkek çocukların anne ve babaları ile ilişkilerinin kız çocuklara göre daha çatışmalı olduğu söylenebilir.

Tablo 3.1. Çocuk Ana-Baba İlişki Ölçeğinin Alt Boyut Puanlarının Çocuğun Yaşına Göre T- Testi Sonuçları

\begin{tabular}{cccccccccc}
\hline $\begin{array}{c}\text { ÇABíö } \\
\text { Alt Boyutları }\end{array}$ & $\begin{array}{c}\text { Yaş } \\
\text { (Ay Grubu) }\end{array}$ & $\mathbf{n}$ & $\overline{\mathbf{X}}$ & Ortanca & Min & Max & ss & $\mathbf{t}$ & $\mathbf{p}$ \\
\hline Anne-Çocuk & $60-65$ Ay & 235 & 15,39 & 15 & 10 & 25 & 3,74 &, 372 &, 710 \\
Olumlu İlişki & $66-72$ Ay & 261 & 15,27 & 14 & 10 & 25 & 3,62 & & \\
\hline Baba-Çocuk & $60-65$ Ay & 141 & 15,69 & 15 & 10 & 29 & 4,42 & \multirow{2}{*}{, 436} &, 663 \\
Olumlu İlişki & $66-72$ Ay & 165 & 15,48 & 15 & 10 & 26 & 3,89 & & \\
\hline
\end{tabular}


Tablo 3.1 incelendiğinde örneklem grubunun Çocuk Ana-Baba İlişki Ölçeğinin ana-çocuk olumlu ilişki alt boyutu ile baba- çocuk olumlu ilişki alt boyutundan almış oldukları puanların, çocuğun yaşına göre anlamlı bir farklılık göstermediği görülmektedir ( $p>0,05)$.

Tablo 3.2. Çocuk Ana-Baba İlişki Ölçeğinin Alt Boyut Puanlarının Çocuğun Yaşına Göre MannWhitney U Testi Sonuçları

\begin{tabular}{|c|c|c|c|c|c|c|c|c|c|c|}
\hline $\begin{array}{c}\text { ÇABİÖ } \\
\text { Alt Boyutları }\end{array}$ & $\begin{array}{c}\text { Yaş } \\
\text { (Ay Grubu) }\end{array}$ & $\mathbf{n}$ & $\overline{\mathbf{X}}$ & Ortanca & Min & Max & ss & $\begin{array}{c}\text { Sira } \\
\text { Ortalamasi }\end{array}$ & $\mathbf{z}$ & $\mathrm{p}$ \\
\hline Ana-Çocuk & 60-65 Ay & 235 & 30,42 & 29 & 14 & 60 & 9,38 & 257,16 & \multirow{2}{*}{$\begin{array}{c}- \\
1,278\end{array}$} & \multirow{2}{*}{ 201 } \\
\hline Çatışmalı İlişki & 66-72 Ay & 261 & 29,52 & 28 & 15 & 61 & 8,61 & 240,7 & & \\
\hline Baba-Çocuk & 60-65 Ay & 141 & 29,3 & 28 & 14 & 50 & 8,60 & 164,91 & \multirow{2}{*}{$\begin{array}{c}- \\
2,088\end{array}$} & \multirow{2}{*}{, $037^{*}$} \\
\hline Çatışmalı İlişki & 66-72 Ay & 165 & 27,5 & 26 & 14 & 56 & 7,97 & 143,75 & & \\
\hline
\end{tabular}

${ }^{*} \mathrm{p}<0,05$

Tablo 3.2 incelendiğinde örneklem grubunun Çocuk Ana-Baba İlişki Ölçeği'nin ana-çocuk çatışmalı ilişki alt boyutundan almış oldukları puanların, çocuğun yaşına göre anlamlı bir farklılık göstermediği $(p>0,05)$; baba-çocuk çatışmalı ilişki alt boyutundan almış oldukları puanların ise çocuğun yaşına göre anlamlı düzeyde farklılaşttğı görülmektedir $(\mathrm{p}<0,05)$. Bu bulgu sşığında, 6065 aylık çocuk grubunun babaları ile ilişkilerinin 66-72 aylık çocuk grubuna göre daha çatışmalı olduğu söylenebilir.

Tablo 4.1. Çocuk Ana-Baba İlişki Ölçeğinin Alt Boyut Puanlarının Ebeveyn Yaşına Göre KruskallWallis H Testi Sonuçları

\begin{tabular}{|c|c|c|c|c|c|c|c|c|c|c|c|}
\hline $\begin{array}{c}\text { ÇABİÖ } \\
\text { Alt } \\
\text { Boyutları }\end{array}$ & $\begin{array}{c}\text { Ebeveyn } \\
\text { Yaşı }\end{array}$ & $\mathbf{n}$ & $\overline{\mathbf{X}}$ & Ortanca & $\begin{array}{c}\mathrm{Mi} \\
\mathbf{n}\end{array}$ & Max & ss & $\begin{array}{c}\text { Sira } \\
\text { Ortalaması }\end{array}$ & $\mathbf{H}$ & $\mathrm{p}$ & $\begin{array}{c}\text { İkili } \\
\text { Karşılaştırm } \\
\text { a }\end{array}$ \\
\hline \multirow{5}{*}{$\begin{array}{l}\text { Ana-Çocuk } \\
\text { Çatışmalı İlişki }\end{array}$} & \multirow{5}{*}{$\begin{array}{c}25 \text { yaş ve altı } \\
\text { 26- } 30 \text { yaş } \\
\text { 31-35 yaş } \\
\text { 36-40 yaş } \\
41 \text { yaş ve } \\
\text { üzeri }\end{array}$} & 26 & 16,73 & 31 & 19 & 55 & 4,38 & 280,13 & \multirow{5}{*}{7,513} & \multirow{5}{*}{ 111 } & \\
\hline & & 123 & 15,32 & 28 & 15 & 52 & 3,81 & 249,55 & & & \\
\hline & & 204 & 15,02 & 29 & 14 & 60 & 3,37 & 248,01 & & & \\
\hline & & 121 & 15,58 & 27 & 14 & 61 & 3,78 & 230,05 & & & \\
\hline & & 22 & 15,18 & 33 & 17 & 62 & 3,91 & 311,27 & & & \\
\hline
\end{tabular}

Tablo 4.1 incelendiğinde örneklem grubunun Çocuk Ana-Baba İlişki Ölçeği'nin ana-çocuk çatışmalı ilişki alt boyutunda almış oldukları puanların, anne yaşına göre anlamlı bir farklılık göstermediği görülmektedir ( $\mathrm{p}>0,05)$.

Tablo 4.2 incelendiğinde, örneklem grubunun Çocuk Ana-Baba İlişki Ölçeği'nin ana-çocuk olumlu ilişki, baba-çocuk olumlu ilişki ve baba-çocuk çatışmalı ilişki alt boyutlarından almış oldukları puanların, ebeveyn yaşına göre anlamlı bir farklılık göstermediği görülmektedir ( $p>0,05)$. 
Tablo 4.2. Çocuk Ana-Baba İlişki Ölçeğinin Alt Boyut Puanlarının Ebeveyn Yaşına Göre Tek Yönlü Varyans Analizi (ANOVA) Sonuçları

\begin{tabular}{|c|c|c|c|c|c|c|c|c|c|}
\hline $\begin{array}{c}\text { ÇABİÖ } \\
\text { Alt Boyutları }\end{array}$ & $\begin{array}{c}\text { Ebeveyn } \\
\text { Yaşı }\end{array}$ & $\mathbf{n}$ & $\overline{\mathbf{X}}$ & Ortanca & Min & Max & ss & $\mathbf{F}$ & $\mathrm{p}$ \\
\hline \multirow{5}{*}{$\begin{array}{l}\text { Ana-Çocuk } \\
\text { Olumlu İliş̧ki }\end{array}$} & 25 yaş ve altı & 26 & 16,73 & 16 & 10 & 25 & 4,38 & \multirow{5}{*}{1,463} & \multirow{5}{*}{,212 } \\
\hline & 26-30 yaş & 123 & 15,32 & 14 & 10 & 29 & 3,81 & & \\
\hline & $31-35$ yaş & 204 & 15,02 & 15 & 10 & 25 & 3,37 & & \\
\hline & $36-40$ yaş & 121 & 15,58 & 15 & 10 & 25 & 3,78 & & \\
\hline & 41 yaş ve üzeri & 22 & 15,18 & 14,5 & 10 & 23 & 3,91 & & \\
\hline \multirow{4}{*}{$\begin{array}{l}\text { Baba-Çocuk } \\
\text { Olumlu İlişki }\end{array}$} & 30 yaş ve altı & 31 & 14,87 & 15 & 10 & 23 & 3,15 & \multirow{4}{*}{411} & \multirow{4}{*}{ 745 } \\
\hline & 31- 35 yaş & 112 & 15,53 & 14,5 & 10 & 29 & 4,07 & & \\
\hline & 36- 40 yaş & 112 & 15,69 & 15 & 10 & 28 & 4,26 & & \\
\hline & 41 yaş ve üzeri & 51 & 15,86 & 15 & 10 & 27 & 4,6 & & \\
\hline \multirow{4}{*}{$\begin{array}{c}\text { Baba-Çocuk } \\
\text { Çatışmalı İlişki }\end{array}$} & 30 yaş ve altı & 31 & 27,94 & 25 & 14 & 52 & 8,27 & \multirow{4}{*}{, 528} & \multirow{4}{*}{ 664 } \\
\hline & 31- 35 yaş & 112 & 28,85 & 27 & 15 & 56 & 8,15 & & \\
\hline & 36- 40 yaş & 112 & 27,7 & 26 & 14 & 53 & 8,22 & & \\
\hline & 41 yaş ve üzeri & 51 & 29,08 & 30 & 14 & 49 & 8,54 & & \\
\hline
\end{tabular}

Tablo 5.1. Çocuk Ana İlişki Ölçeğinin Toplam Puanının ve Alt Boyut Puanlarının Anne Öğrenim Durumuna Göre Kruskall-Wallis H Testi Sonuçları

\begin{tabular}{|c|c|c|c|c|c|c|c|c|c|c|c|}
\hline $\begin{array}{c}\text { ÇAİÖ ve } \\
\text { Alt Boyutları }\end{array}$ & $\begin{array}{l}\text { Öğrenim } \\
\text { Durumu }\end{array}$ & $\mathbf{n}$ & $\overline{\mathbf{X}}$ & Ortanca & Min & Max & ss & $\begin{array}{c}\text { Sira } \\
\text { Ortalamasi }\end{array}$ & $\mathbf{H}$ & $\mathbf{p}$ & $\begin{array}{c}\text { İkili } \\
\text { Karşılaştırma }\end{array}$ \\
\hline Ana-Çocuk & (1)İlköğretim ve öncesi & 129 & 15,95 & 15 & 10 & 29 & 4,17 & 266,3 & \multirow{3}{*}{5,97} & \multirow{3}{*}{051} & \\
\hline Olumlu İlişki & (2)Ortaöğretim & 191 & 14,81 & 14 & 10 & 25 & 3,39 & 229,34 & & & \\
\hline Alt Boyutu & (3)Yükseköğretim & 176 & 15,43 & 15 & 10 & 24 & 3,52 & 256,25 & & & \\
\hline Ana-Çocuk & $\begin{array}{c}\text { (1)İlköğretim ve } \\
\text { öncesi }\end{array}$ & 129 & 34,02 & 32 & 14 & 62 & 10,63 & 302,71 & \multirow{3}{*}{25,06} & \multirow{3}{*}{, $000^{*}$} & \multirow{3}{*}{$\begin{array}{l}1-2 \\
1-3\end{array}$} \\
\hline Çatışmalı İlişki & (2)Ortaöŏretim & 191 & 28,8 & 28 & 14 & 54 & 7,78 & 231,59 & & & \\
\hline Alt Boyutu & (3)Yükseköğretim & 176 & 28,55 & 24 & 15 & 52 & 7,92 & 227,12 & & & \\
\hline
\end{tabular}

${ }^{*} p<0,05$

Tablo 5.1 incelendiğinde örneklem grubunun “Çocuk Ana İlişki Ölçeği” nden, ölçeğin ana-çocuk çatışmalı ilişki alt boyutlarından aldıkları puanların, anne öğrenim durumuna göre anlamlı düzeyde farklılaştığı görülmektedir $(p<0,05)$. Ana-çocuk çatışmalı ilişki alt boyutu puanları açısından söz konusu farklılığın hangi gruplarda meydana geldiğini ortaya koymak amacıyla yapılan ikili karşılaştırma sonucunda, anne öğrenim durumu ilköğretim ve öncesi olan grup ile anne öğrenim durumu ortaöğretim olan grup arasında; anne öğrenim durumu ilköğretim ve öncesi olan grup ile anne öğrenim durumu yükseköğretim olan grup arasında anlamlı bir farklılık olduğu görülmüştür. Bu bulgu ışığında anne öğrenim durumu ilköğretim ve öncesi olan çocukların anneleri ile ilişkilerinin anne öğrenim durumu ortaöğretim ve yükseköğretim olan çocukların anneleri ile ilişkilerine göre daha çatışmalı olduğu söylenebilir. 
Tablo 5.2. Çocuk Baba İlişki Ölçeği'nin Toplam Puanının ve Alt Boyut Puanlarının Baba Öğrenim Durumuna Göre Tek Yönlü Varyans Analizi (ANOVA) Sonuçları

\begin{tabular}{|c|c|c|c|c|c|c|c|c|c|}
\hline $\begin{array}{c}\text { ÇBíÖ ve } \\
\text { Alt Boyutları }\end{array}$ & $\begin{array}{l}\text { Öğrenim } \\
\text { Durumu }\end{array}$ & $\mathbf{n}$ & $\overline{\mathbf{X}}$ & Ortanca & Min & Max & ss & $\mathbf{F}$ & p \\
\hline Baba-Çocuk & İlköğretim ve öncesi & 75 & 15,73 & 15 & 10 & 29 & 4,46 & & \\
\hline Olumlu İlişki & Ortaöğretim & 108 & 15 & 14,5 & 10 & 27 & 3,99 & 1,704 & ,184 \\
\hline Alt Boyutu & Yükseköğretim & 123 & 15,98 & 15 & 10 & 28 & 4,04 & & \\
\hline Baba-Çocuk & İlköğretim ve öncesi & 75 & 28,87 & 27 & 14 & 52 & 8,76 & & \\
\hline Çatışmalı İlişki & Ortaöğretim & 108 & 27,91 & 26 & 14 & 56 & 8,59 & ,316 & ,729 \\
\hline Alt Boyutu & Yükseköğretim & 123 & 28,48 & 28 & 14 & 50 & 7,62 & & \\
\hline
\end{tabular}

Tablo 5.2 incelendiğinde örneklem grubunun “Çocuk Baba İlişki Ölçeği” nden, ölçeğin baba-çocuk olumlu ilişki ve baba-çocuk çatışmalı ilişki alt boyutlarından almış oldukları puanların, baba öğrenim durumuna göre anlamlı farklılık göstermediği görülmektedir ( $p>0,05)$.

Tablo 6. Çocuk Ana-Baba İlişki Ölçeğinin Toplam Puanının ve Alt Boyut Puanlarının Ailenin Gelir Durumuna Göre Tek Yönlü Varyans Analizi (ANOVA) Sonuçları

\begin{tabular}{|c|c|c|c|c|c|c|c|c|c|c|}
\hline $\begin{array}{c}\text { ÇABİÖ ve } \\
\text { Alt Boyutları }\end{array}$ & Gelir Durumu & $\mathbf{n}$ & $\overline{\mathbf{X}}$ & Ortanca & Min & Max & ss & $\mathbf{F}$ & p & $\begin{array}{c}\text { İkili } \\
\text { Karşılaştırma }\end{array}$ \\
\hline \multirow{4}{*}{$\begin{array}{l}\text { Ana-Çocuk } \\
\text { Olumlu İlişki } \\
\text { Alt Boyutu }\end{array}$} & $1.500 \mathrm{TL}$ ve alt 1 & 76 & 15,87 & 15 & 10 & 25 & 4,11 & \multirow{4}{*}{ 692 } & \multirow{4}{*}{, 557} & \\
\hline & $1.501-3.000 \mathrm{TL}$ & 193 & 15,17 & 15 & 10 & 25 & 3,76 & & & \\
\hline & 3.001- $4.500 \mathrm{TL}$ & 131 & 15,31 & 14 & 10 & 25 & 3,43 & & & \\
\hline & 4.501 TL ve üzeri & 96 & 15,24 & 14 & 10 & 24 & 3,45 & & & \\
\hline \multirow{4}{*}{$\begin{array}{c}\text { Ana-Çocuk } \\
\text { Çatışmalı İlişki } \\
\text { Alt Boyutu }\end{array}$} & (1)1.500 TL ve alt1 & 76 & 33,64 & 32 & 16 & 61 & 10,72 & \multirow{4}{*}{$\begin{array}{c}8,06 \\
1\end{array}$} & \multirow{4}{*}{, $000^{*}$} & \\
\hline & (2)1.501-3.000 TL & 193 & 30,65 & 29 & 15 & 60 & & & & \\
\hline & (3)3.001-4.500 TL & 131 & 29,11 & 28 & 15 & 54 & 8,59 & & & $1-4$ \\
\hline & (4)4.501 TL ve üzeri & 96 & 27,36 & 27 & 14 & 51 & 7,67 & & & $2-4$ \\
\hline \multirow{4}{*}{$\begin{array}{l}\text { Baba-Çocuk } \\
\text { Olumlu İlişki } \\
\text { Alt Boyutu }\end{array}$} & $1.500 \mathrm{TL}$ ve altı & 39 & 14,97 & 14 & 10 & 29 & 4,74 & \multirow{4}{*}{,353 } & \multirow{4}{*}{,787 } & \\
\hline & $1.501-3.000 \mathrm{TL}$ & 111 & 15,7 & 15 & 10 & 27 & 3,92 & & & \\
\hline & $3.001-4.500 \mathrm{TL}$ & 86 & 15,73 & 15 & 10 & 26 & 3,99 & & & \\
\hline & 4.5001TL ve üzeri & 70 & 15,51 & 14 & 10 & 28 & 4,35 & & & \\
\hline \multirow{4}{*}{$\begin{array}{c}\text { Baba-Çocuk } \\
\text { Çatışmalı İlişki } \\
\text { Alt Boyutu }\end{array}$} & $1.500 \mathrm{TL}$ ve altı & 39 & 29,46 & 28 & 14 & 52 & 9,36 & \multirow{4}{*}{1,55} & \multirow{4}{*}{ 202 } & \\
\hline & $1.501-3.000 \mathrm{TL}$ & 111 & 29,3 & 27 & 14 & 56 & 7,65 & & & \\
\hline & $3.001-4.500 \mathrm{TL}$ & 86 & 27 & 26 & 14 & 50 & 8,55 & & & \\
\hline & 4.5001TL ve üzeri & 70 & 27,99 & 25 & 16 & 29 & 7,98 & & & \\
\hline
\end{tabular}

${ }^{*} \mathrm{p}<0,05$ 
Tablo 6 incelendiğinde, örneklem grubunun Çocuk Ana İlişki Ölçeğinin ana-çocuk olumlu ilişki alt boyutundan, Çocuk Baba İlişki Ölçeğinden, ölçeğin baba-çocuk olumlu ilişki ile baba-çocuk çatışmalı ilişki alt boyutlarından almış oldukları puanların ailenin gelir durumuna göre anlamlı bir farklılık göstermediği ( $p>0,05)$; Çocuk Ana İlişki Ölçeğinden, ölçeğin ana-çocuk çatışmalı ilişki alt boyutundan almış oldukları puanların ise aile gelir durumuna göre anlamlı düzeyde farklılaştığı görülmektedir $(\mathrm{p}<0,05)$.

Ana-çocuk çatışmalı ilişki alt boyut puanları açısından söz konusu farklılığın hangi gruplarda meydana geldiğini ortaya koymak amacıyla yapılan ikili karşılaştırma sonucunda, aile geliri 1.500 TL ve altında olan grup ile aile geliri 3.001 TL-4.500 TL aralığında olan grup arasında; aile geliri $1.500 \mathrm{TL}$ ve altında olan grup ile aile geliri $4.501 \mathrm{TL}$ ve üzerinde olan grup arasında; aile geliri 1.501 TL-3.000 TL aralığında olan grup ile aile geliri 4.501 TL ve üzerinde olan grup arasında anlamlı bir farklılık olduğu görülmüştür. Bu bulgu ışığında aile geliri $1.500 \mathrm{TL}$ ve altında olan annelerin çocukları ile ilişkilerinin aile gelir 3.001 TL-4.500 TL aralığında olan anneler ile aile geliri 4.501 TL ve üzerinde olan annelerin çocukları ile ilişkilerine göre daha çatışmalı olduğu; aile geliri 1.501 TL3.000 TL aralığında olan annelerin çocukları ile ilişkilerinin ise aile geliri 4.501 TL ve üzerinde olan annelerin çocukları ile ilişkilerine göre daha çatışmalı olduğu söylenebilir.

\section{TARTIŞMA, SONUÇ ve ÖNERILLER}

Demografik değişkenler açısından ebeveyn ile çocuk arasındaki ilişkilerin incelendiğinde bu araştırmada bulguları, anne ile çocuk arasındaki olumlu ilişkinin çocuğun cinsiyetine göre anlamlı düzeyde farklılaşmadığı; baba ile çocuk arasındaki olumlu ilişkinin ise çocuğun cinsiyetine göre anlamlı düzeyde farklılaştığı sonucunu ortaya koymaktadır. Buna göre babaların kız çocukları ile ilişkilerinin erkek çocuklara göre daha olumlu olduğu görülmektedir (Bkz. Tablo 2.1). Anne ile çocuk arasındaki olumlu ilişkinin cinsiyete göre farklılık göstermediği yönündeki bulgu, anneliğin içgüdüsel olması ile açıklanabilir. Öyle ki annelerin çocukları ile kurduğu olumlu ilişki çocuğun cinsiyetinden etkilenmemektedir. Diğer yandan babaların kızları ile ilişkilerinin daha olumlu olması ise Freud'un psikoanalitik teorisinde belirttiği gibi fallik dönemdeki kız çocuğun babaya duyduğu ilgi ve hayranlık ile açıklanabilir. Literatürdeki çalışmaların büyük bir bölümü kız çocukların erkek çocuklara göre daha sakin ve uyumlu oldukları, sosyal becerilerinin daha yüksek olduğu sonucunu ortaya koymaktadır (Çiftçi Topaloğlu, 2013; Laibe ve arkadaşları, 2004; Anthony ve arkadaşları, 2005; Yener, 2015; Elibol Gültekin, 2008; Karaca, Gündüz ve Aral, 2012). Dolayısıyla bu bulguda kız çocukların söz konusu özelliklerinin de rolü olabileceği düşünülmektedir. Literatürde araştırma bulgusu ile örtüşen çalışmalar bulunmaktadır. Örneğin; Özdemir (2012), okul öncesi dönemki çocukların ebeveynleri ile yürüttüğü çalışmada annelerin ebeveynliğe ilişkin ilgi ve doyumlarının sahip oldukları çocuğun cinsiyetine göre farklılaşmadığı, ancak kız çocuğa sahip babaların ebeveynlik ilgi ve doyumlarının erkek çocuğa sahip babalardan daha yüksek olduğu sonucuna ulaşmıştır. Driscoll ve Pianta (2011), erken çocukluk dönemindeki çocukların ebeveynleri ile ilişkilerini 3 yıl boyunca incelendikleri çalışmada babaların kız çocukları ile ilişkilerinin daha yakın olduğu sonucuna ulaşmışlardır. Bir diğer çalışmada da kız çocuğu olan babaların çocuk yetiştirme aktivitelerine katılımının erkek çocuğu olan babalardan daha yüksek olduğu saptanmıştır (Mcbride ve arkadaşları, 2002). Literatür incelendiğinde anne ile çocuk arasındaki olumlu ilişkinin çocuğun cinsiyetine göre değişmediği yönündeki bulguyu destekleyen, ancak baba ile kız çocuk arasındaki ilişkinin erkek çocuklara göre daha olumlu olduğu yönündeki bulguyu desteklemeyen araştırmaların bulunduğu görülmektedir. Örneğin; Kök (2017), okul öncesi dönemdeki çocuklar ve ebeveynleri ile yaptığı çalışmada anne, baba ve çocuk arasındaki ilişkinin çocuğun cinsiyetine göre farklılık göstermediği sonucunu ortaya koymaktadır. Tarkoçin (2014) de çalışmasında anne, baba ve çocuk arasındaki iletişimin çocuğun cinsiyetine göre değişiklik göstermediğini saptamıştır. İlgili araştırmaların sonuçları arasındaki farklılıkların, 
örneklem gruplarının demografik özelliklerindeki farklılıklardan veya araştırmalarda kullanılan ölçme araçlarının çeşitliliğinden kaynaklanmış olabileceği düşünülmektedir.

Araştırma bulguları, anne ile çocuk arasındaki çatışmalı ilişkinin ve baba ile çocuk arasındaki çatışmalı ilişkinin çocuğun cinsiyetine göre anlamlı düzeyde farklılaştığı sonucunu ortaya koymaktadır. Buna göre anne ve babaların erkek çocukları ile ilişkilerinin daha çatışmalı olduğu görülmektedir (Bkz. Tablo 2.2). Bu bulgu yapılan araştırmaların büyük bir bölümünün gösterdiği gibi erkek çocukların daha saldırgan, hareketli ve uyumsuz olmaları ile açıklanabilir (Ladd ve Profilet, 1996; Altay ve Güre, 2012; Sall, 2014; Uluyurt, 2012; Keown, 2000; Dursun, 2010; Tarkoçin, 2014; Gür, 2016; Ertürk Kara ve Gürgen, 2016). Ayrıca bu bulgu, ebeveynlerin cinsiyetçi bir yaklaşım ile kız ve erkek çocuklara karşı farklı davranıyor olabileceklerini de düşündürmektedir. Literatürde araştırma bulgusunu destekleyen çalışmaların olduğu görülmektedir. Sayg1 (2011)'nın çalışma bulguları incelendiğinde aradaki fark istatistiksel açıdan anlamlı olmasa da okul öncesi dönemdeki erkek çocukların anneleri ile arasındaki ilişkinin kız çocuklarına göre daha çatışmalı olduğu dikkat çekmektedir. Barnett ve arkadaşları (2008) da çalışmalarında babaların erkek çocukları ile ilişkilerinin daha olumsuz olduğu sonucuna ulaşmışlardır. Gençtoprak (2010)'ın çalışma bulguları incelendiğinde hem anne hem de baba için ebeveyn çocuk ilişkisindeki red düzeyinin kızlara oranla erkeklerde daha fazla olduğu görülmektedir. Dwairy (2010)'nin Arjantinli, Arap, Fransız, Hintli ve Polonyalı 2884 ergen ile yürüttüğü araştırma sonucunda ulaştığ1 erkeklerin, kızlara oranla daha fazla ebeveyn reddi ve daha az ebeveyn kabulü algıladıkları yönündeki bulgu, söz konusu ebeveyn-çocuk ilişkisinin ergenlik döneminde de benzer nitelikte olabileceğini düşündürmektedir. Diğer taraftan literatürde araştırma bulgularıyla uyuşmayan çalışmalar da bulunmaktadır. Örneğin; Kök (2017), okul öncesi dönemdeki çocuklar ve ebeveynleri ile yaptığ çalışmada anne-baba-çocuk ilişkisinin çocuğun cinsiyetine göre farklılık göstermediği sonucunu ortaya koymaktadır. 48-72 aylık çocuklar ile yürütülen bir başka çalışmanın bulguları, anne baba ve çocuk iletişiminin çocuğun cinsiyetine göre farklılaşmadığını göstermektedir (Arabac1, 2011). Benzer şekilde Zhang ve Chen (2010), okul öncesi dönemdeki 100 Çinli çocuğun ebeveynleri ile yürüttükleri çalışmada anne, baba ile çocuk arasındaki ilişkinin çocuğun cinsiyetine göre farklılaşmadığını saptamışlardır. Araştırmaların örneklem gruplarındaki farklılıkların, kültürel farklılıkların ve ölçme araçlarındaki farklılıkların araştırma sonuçları arasındaki farklılığa neden olmuş olabileceği düşünülmektedir.

Araştırma bulguları incelendiğinde anne ile çocuk arasındaki olumlu ilişkinin ve baba ile çocuk arasındaki olumlu ilişkinin çocuğun yaşına göre anlamlı bir farklılık göstermediği görülmektedir (Bkz. Tablo 3.1). Bu bulgu üzerinden ebeveynlerin çocuklarıyla kurduğu sıcak ilişkilerin çocuğun yaşından etkilenmediği söylenebilir. Ayrıca araştırmada karşılaştırma yapılan yaş gruplarının birbirine yakın olmasının da bu sonuçta rolü olabileceği düşünülmektedir. Diğer taraftan baba ile çocuk arasındaki çatışmalı ilişkinin çocuğun yaşına göre anlamlı düzeyde farklılaştığ $;$; 60-65 aylık çocuk grubunun babaları ile ilişkilerinin 66-72 aylık çocuk grubuna göre daha çatışmalı olduğu görülmektedir (Bkz. Tablo 3.2). Karşılaştırma yapılan yaş gruplarının birbirine yakın olmasına rağmen anlamlı bir farklılığın olması şaşırtıcı bulunmuştur. Bu sonucun okul öncesi dönemdeki çocuğun sosyal gelişim hızını ortaya koyduğu söylenebilir. Ayrıca araştırma bulguları incelendiğinde aradaki fark istatistiksel açıdan anlamlı olmasa da 60-65 aylık çocukların anneleri ile ilişkilerinin de 66-72 aylık çocuklara göre nispeten daha çatışmalı olduğu görülmektedir (Bkz. Tablo 3.2). Küçük yaştaki çocukların sosyalizasyon deneyimlerinin büyük yaştaki çocuklara göre daha az olma olasılığı ve kendilerini ifade edebilme becerilerinin daha az gelişmiş olma olasılığı, ilişkilerinde daha fazla çatışma yaşamalarına neden olmuş olabilir. İlgili literatürde birbirleri ile uyuşmayan sonuçların olduğu görülmektedir. Kök (2017), okul öncesi dönemdeki 202 çocuk ve ebeveynleri ile yürüttüğü çalışmada anne-çocuk ilişkisinin ve baba-çocuk ilişkisinin çocuğun yaşına göre farklılık göstermediğini görmüştür. Saygı (2011), ise çalışmasında araştırma bulgusuna 
paralel olarak anne ile çocuk arasındaki yakın ilişkinin çocuğun yaşına göre değişiklik göstermediğini, ancak araştırma bulgusunun aksine 72-78 ay çocuk grubunun 60-72 ay çocuk grubuna göre anneleri ile ilişkilerinin daha çatışmalı olduğunu görmüştür. Araştırma sonuçları arasındaki bu farklılığın örneklem gruplarındaki farklılıklardan ya da karşılaştırma yapilan yaşların farklı şekillerde belirlenmesinden kaynaklanmış olabileceği düşünülmektedir.

Araştırma bulguları, baba ile çocuk arasındaki ilişkinin babanın öğrenim durumuna göre farklılık göstermediği (Bkz. Tablo 5.2); anne ile çocuk arasındaki ilişkinin ise annenin öğrenim durumuna göre farklılık gösterdiği sonucunu ortaya koymaktadır (Bkz. Tablo 5.1). Buna göre annesi ilköğretim ve öncesi mezunu olan çocukların anneleri ile aralarındaki ilişkinin annesi ortaöğretim ve yükseköğretim mezunu olan çocuklara göre daha çatışmalı olduğu görülmektedir. Anne eğitim düzeyindeki artışın, annelerin çocuklarının ihtiyaçlarını daha iyi anlamalarına, çocuk yetiştirme konusunda daha bilinçli olmalarına, ebeveynlik becerilerinin daha yüksek olmasına, geleneksel ebeveyn tutumlarından uzaklaşmalarına, çocuklarının farklılıklarını daha kolay kabullenmelerine ve gerekli durumlarda uzman desteğine erişim konusunda daha bilgili olmalarına katkı sağlamış olabileceği; tüm bunların da annelerin çocukları ile ilişkisine olumlu şekilde yansımış olabileceği düşünülmektedir. Diğer yandan bu bulgunun, yaygın olarak kabul edilen anne ve babanın çocuğun yetiştirilmesinde aldığı sorumluluğun eşit olmadığı yönündeki görüşü desteklediği düşünülmektedir (Erkal ve arkadaşları, 2007). Öyle ki annenin öğrenim durumu çocuğu ile ilişkisini etkilerken babanın öğrenim durumu çocuğu ile ilişkisini etkilememektedir. Bu bulgudan yola çıkarak babaların öğrenim durumu ne olursa olsun geleneksel rollerden uzaklaşmadıkları da düşünülebilir. İlgili literatür incelendiğinde araştırma bulgusunu destekleyen çalışmaların olduğu görülmektedir. Kök (2017), okul öncesi dönemdeki çocuklar ve ebeveynleri ile yaptığı çalışmada öğrenim durumu ortaokul olan annelerin öğrenim durumu önlisans, lisans ve lisansüstü olan annelere göre çocuklarıyla ilişkisinin daha çatışmalı olduğunu görmüştür. Yüksek Usta (2014), okulöncesi dönemdeki 252 çocuk, annesi ve öğretmenleri ile yürüttüğü çalışmada üniversite ve yüksek lisans mezunu annelerin çocukları ile ilişkilerinin ilköğretim ve lise mezunu annelere göre daha yakın olduğu; ilköğretim ve lise mezunu annelerin çocukları ile ilişkilerinin üniversite ve yüksek lisans mezunu annelere göre daha olumsuz ve çatışmalı olduğu sonucuna ulaşmıştır. Saygı (2011)'nın çalışmasında ilköğretim mezunu annelerin çocukları ile ilişkilerinin, lise ve üniversite mezunu annelerden daha çatışmalı olduğu görülmektedir. Özdemir (2012), okul öncesi dönemki çocukların ebeveynleri ile yürüttüğü çalışmada yükseköğretim mezunu annelerin anneliğe ilgilerinin ilköğretim mezunu annelere göre daha fazla olduğu sonucuna ulaşmıştır. Gutman ve Feinstein (2010), anne eğitim düzeyi ile birlikte anne ile çocuk arasındaki olumlu ilişkinin de arttığını belirtmektedir. Çakıcı (2006) tarafından yapılan çalı̧̧manın bulguları, öğrenim düzeyi düşük annelerin çocukları ile ilişkilerinin öğrenim düzeyi yüksek annelere göre daha sağlıksız olduğu yönündedir. Gençtoprak (2010) çalışmasında anne eğitim düzeyi yükseldikçe çocuğun annesi ile ilişkisindeki kabul düzeyinin arttığını görmüştür. Olumlu ebeveyn tutumlarının ebeveyn ile çocuk arasındaki ilişkiyi olumlu şekilde, olumsuz ebeveyn tutularının ise ebeveyn ile çocuk arasındaki ilişkiyi olumsuz şekilde etkileyeceği düşünülmektedir. Dolayısıyla ebeveyn ile çocuk arasındaki ilişkilerin belirleyicilerinden biri olan ebeveyn tutumlarının ele alındığı çalışmalardaki annelerin eğitim düzeyi yükseldikçe demokratik ebeveyn tutumlarının arttığı yönündeki bulguların araştırma bulgusunu destekler nitelikte olduğu söylenebilir (Şendoğdu, 2000; Özyürek, 2005; Tezel Şahin ve Özyürek, 2008). Literatürde araştırma bulgusu ile uyuşmayan çalışmaların da bulunduğu görülmektedir. Örneğin; Saygı (2011)'nın çalışmasında, araştırma bulgularının aksine öğrenim düzeyi ilköğretim olan annelerin çocukları ile arasındaki ilişkinin, öğrenim düzeyi lise ve üniversite olan annelerin çocukları ile arasındaki ilişkiden daha olumlu olduğunu görmüştür. Araştırmaların örneklem gruplarındaki farklılıkların, araştırmaların farklı özelliklerdeki il ve ilçelerde yürütülmüş olmasının, araştırma bulguları arasındaki farklılığın nedenleri arasında gösterilebileceği düşünülmektedir. 
Araştırma bulguları, baba ile çocuk arasındaki olumlu, çatışmalı ve genel ilişkinin ailenin gelir durumuna göre anlamlı bir farklılık göstermediği; anne ile çocuk arasındaki çatışmalı ve genel ilişkinin ise aile gelir durumuna göre anlamlı düzeyde farklılaştığ ${ }_{1}$ sonucunu ortaya koymaktadır (Bkz. Tablo 6). Buna göre aile geliri 3.001TL-4.500TL aralığında olan anneler ile aile geliri 4.501TL ve üzerinde olan annelerin çocukları ile ilişkilerinin aile geliri $1.500 \mathrm{TL}$ ve altında olan annelerin çocukları ile ilişkilerine göre daha yakın ve sıcak olduğu görülmektedir (Bkz. Tablo 4.13). Diğer taraftan aile geliri 1.500 TL ve altında olan annelerin çocukları ile ilişkilerinin aile geliri 3.001TL4.500TL aralığında olan anneler ile aile geliri 4.501TL ve üzerinde olan annelerin çocukları ile ilişkilerine göre daha çatışmalı olduğu; aile geliri 1.501 TL-3.000TL aralığında olan annelerin çocukları ile ilişkilerinin aile geliri 4.501TL ve üzerinde olan annelerin çocukları ile ilişkilerine göre daha çatışmalı olduğu görülmektedir (Bkz. Tablo 6). Baba ile çocuk arasındaki ilişkinin aile gelir durumundan etkilenmeyip anne ile çocuk arasındaki ilişkinin aile gelir durumundan etkilenmesi, ailedeki gelir gider hesaplamasının annelerin sorumluluğunda olabileceğini düşündürmektedir. Buradan yola çıarak bu bulgunun, aile gelirindeki düşüş ile yaşanabilecek ekonomik sıkıntıların annede kaygı ve strese neden olabileceğini, yaşanacak kaygı ve stresin de aile içi ilişkilere olumsuz şekilde yansımış olabileceğini düşündürdüğü söylenebilir. Literatür incelendiğinde araştırma sonuçları arasında farklılıkların olduğu görülmektedir. Örneğin; Çakıcı (2006)'nın çalışmasında ulaştığı, düşük sosyoekonomik düzeydeki annelerin çocuklarıyla ilişkilerinin yüksek sosyoekonomik düzeydeki annelerden daha sağlıksız olduğu yönündeki sonuç, araştırma bulgusunu desteklemektedir. Benzer şekilde araştırma bulgusuna paralel olarak Arabacı (2011) da çalışmasında, sosyo-ekonomik düzeyin yüksek olduğu ailelerde anne ile çocuk arasındaki iletişiminin daha iyi olduğu sonucunu ortaya koymaktadır. Diğer taraftan Kök (2017) ve Saygı (2011) okul öncesi dönemdeki çocuklar ve ebeveynleri ile yaptıkları çalışmalarda anne-baba ile çocuk arasındaki ilişkinin sosyo-ekonomik duruma göre değişmediği sonucuna ulaşmışlardır. Araştırma bulguları arasındaki farklılıkların, örneklem gruplarındaki farklılıklardan, çalışmaların yürütüldüğü il ve ilçelerin özelliklerinden, çalışmalarda sosyo-ekonomik düzey için ele alınan kriterlerin ve gelir aralıklarının farklılıklarından kaynaklanmış olabileceği düşünülmektedir.

Araştırmada 5-6 yaş grubu çocukların ebeveynleriyle ilişkileri demografik değişkenler kapsamında incelenmiştir. Ebeveyn- çocuk ilişkilerinin, çocuğun hayatının ilerleyen süreçlerinde kuracağ1 ilişkilerin temelini oluşturduğu düşünüldüğünde, ebeveyn- çocuk ilişkilerinin inceleneceği çalışmaların literatüre önemli katkı sağlayacağı söylenebilir. Bu bağlamda farklı örneklem grupları ile de benzer çalışmaların yürütülmesi ve ebeveyn-çocuk ilişkilerinin farklı değişkenler açısından da ele alınması önerilebilir. Ayrıca yapılacak çalışmalarda ebeveyn- çocuk ilişkilerinde yaşanan sorunların çözümüne yönelik müdahale programları geliştirilerek geliştirilen programların etkisi incelenebilir. Diğer yandan alan uzmanlarına, ebeveyn-çocuk arasındaki olumlu ilişkinin desteklenmesi amacıyla eğitim düzeyi ve ekonomik düzeyi düşük anneler başta olmak üzere ebeveynlere, iletişim becerileri, ebeveyn tutumları, çocuğa yaklaşım gibi konularda eğitimler düzenlenmesi önerilebilir.

\section{KAYNAKÇA}

Akgün, E., Yeşilyaprak, B. (2010). Çocuk Ana-Baba İlişki Ölçeği Türkçe Formunun Geçerlik ve Güvenirlik Çalışması. Balıkesir Üniversitesi Sosyal Bilimler Enstitüsü, 13(24), 31-43.

Altay, F.B., ve Güre, A. (2012). Okulöncesi kuruma (devlet-özel) devam eden çocukların sosyal yeterlik ve olumlu sosyal davranışları ile annelerinin ebeveynlik stilleri arasındaki ilişkiler. Kuram ve Uygulamada Ĕ̆itim Bilimleri, 12(4), 2699-2718. 
Anthony, L.G., Anthony, B.J., Glanville, D.N., Naiman, D.Q., Waanders, C., and Shaffer, S. (2005). The relationships between parenting stress, parenting behaviour and preschoolers' social competence and behaviour problems in the classroom. Infant and Child Development, 14(2), 133-154.

Arabacı, N. (2011). Anne-Baba-Çocuk İletişimini Değerlendirme Aracı'nın (ABÇİDA) geliştirilmesi ve anne-baba-çocuk iletişiminin bazı değişkenler açısından incelenmesi. Doktora Tezi, Gazi Üniversitesi, Ankara.

Barnett, M.A, Deng, M., Mills-Koonce, W.R., Willoughby, M., and Cox, M. (2008). Interdependence of parenting of mothers and fathers of infants. Journal of Family Psychology, 22(3), 561-573.

Camarneiro, A. P. F., and de Miranda Justo, J. M. R. (2017). Prenatal attachment and sociodemographic and clinical factors in Portuguese couples. Journal of Reproductive and Infant Psychology, 35(3), 212-222.

Çağdaş, A. (2009). Anne-Baba-Çocuk İletişimi. 2. basım. Ankara: KÖK Yayıncılık.

Çakıcı, S. (2006). Alt ve üst sosyoekonomik düzeydeki ailelerin aile işlevlerinin, anne çocuk ilişkilerine etkisinin incelenmesi. Yüksek Lisans Tezi, Gazi Üniversitesi, Ankara.

Çiftçi Topaloğlu, Z. (2013). 4-5 yaş çocuklarının sosyal yetkinlik, saldırganlık, kaygı düzeyleri ile anne-babalarının ebeveyn özyeterliği algısı arasındaki ilişkilerin incelenmesi. Yüksek Lisans Tezi, Pamukkale Üniversitesi, Denizli.

Dwairy, M. (2010). Parental acceptance-rejection: a fourth cross-cultural research on parenting and psychological adjustment of children. Journal of Child and Family Studies, 19, 30-35.

Driscoll, K., and Pianta, R.C. (2011). Mothers' and fathers' perceptions of conflict and closeness in parent-child relationships during early childhood. Journal of Early Childhood E Infant Psychology, $1(7), 1-24$.

Dursun, A. (2010). Okul öncesi dönemdeki çocukların davranış problemleriyle anne-baba tutumları arasındaki ilişkinin incelenmesi. Yüksek Lisans Tezi, Dokuz Eylül Üniversitesi, İzmir.

Eisenberg, N., Gershoff, T.E., Fabes, A.R., Shepard, A.S., Cumberland, J.A., Losaya, H.S., Guthrie, K.I., and Murphy, C.B. (2001). Mother's emotional expressivity and child's behavior problems and social competence: mediation through children's regulation. Developmental Psychology, 37(4), 475490.

Erel, O., and Burman, B. (1995). Interrelatedness of marital relations and parent-child relations: A meta-analytic review. Psychological Bulletin, 118(1), 108-132.

Erkal, S., Copur, Z., Doğan, N., and Şafak, S. (2007). Examining the relationship between parents' gender roles and responsibilities towards their children (A Turkish example). Social Behavior and Personality, 35(9), 1221-1234.

Ertürk Kara, H.G., and Gürgen, F. (2016). 48-72 aylık çocukların davranış sorunlarının çeşitli değişkenler açısından incelenmesi. International Journal of Social Sciences and Education Research, 2(4), 1494- 1505.

Elibol Gültekin, S. (2008). 5 yaş çocuklarının sosyal becerilerinin bazı değişkenler açısından değerlendirilmesi. Yüksek Lisans Tezi, Ankara Üniversitesi, Ankara.

Field, A. (2009). Discovering statistics using SPSS. New Delhi: Sage publications.

Fishman, E.A., and Meyers, S.A. (2000). Marital satisfaction and child adjustment: Direct and mediated pathways. Contemporary Family Therapy, 22(24), 437-452. 
Gençtoprak, S. (2010). Çocukların anne-babalarıyla ilişkide kabul veya red algıları, psikolojik uyumları ve akademik başarılarının incelenmesi. Yüksek Lisans Tezi, Karaelmas Üniversitesi, Zonguldak.

Gutman, L.M., and Feinstein, L. (2010). Parenting behaviours and children's development from infancy to early childhood: Changes, continuities and contributions. Early Child Development and Care, 180(4), 535-556.

Gür, A. (2016). Çocuk evlerinde yaşayan çocuklar ile ailesiyle birlikte yaşayan çocukların akran ilişkileriyle sosyal davranışlarının incelenmesi. Yüksek Lisans Tezi, Gazi Üniversitesi, Ankara.

Hortaçsu, N. (2003). Çocuklukta İlişkiler Ana Baba, Kardeş ve Arkadaşlar. Ankara: İmge Kitabevi.

Hortaçsu, N. (2012). İnsan İlişkileri. 4. basım. Ankara: İmge Kitapevi.

Israel, G.D. (1992). Determining sample size. University of Florida.

Kandır, A., ve Alpan, Y. (2008). Okul öncesi dönemde sosyal-duygusal gelişime anne-baba davranışlarının etkisi. Sosyal Politika Çalışmaları Dergisi, 14(14), 33-38.

Karaca, N.H., Gündüz, A., ve Aral, N. (2011). Okul öncesi dönem çocuklarının sosyal davranışının incelenmesi. Kuramsal Eğitimbilim Dergisi, 4(2), 65-76.

Karasar, N. (2014). Bilimsel araştırma yöntemleri. 26. basım. Ankara: Nobel.

Kimonis, E.R., Frick, P.J., Boris, N.W., Smyke, A.T., Cornell, A.H., Farrell, J.M., and Zeanah, C.H. (2006). Callous- Unemotional features, behavioral inhibition, and parenting: independent predictors of aggression in a high-risk preschool sample. Journal of Child and Family Study, 15, 745756.

Keown, L.J. (2000). Parent-child relationships, peer functioning, and preschool hyperactivity. PhD thesis, The University of Auckland, USA.

Kök, E.E. (2017). Anaokuluna devam eden çocukların ebeveynleri ile ilişkilerinin çocukların oyun davranışlarına yansımasının incelenmesi. Yüksek Lisans Tezi, Akdeniz Üniversitesi, Antalya.

Ladd, G.W., Profilet, S.M. (1996). The Child Behavior Scale: A teacher-report measure of young children's aggressive, withdrawn, and prosocial behaviors. Developmental Psychology, 32(6), 10081024.

Laible, D. J., Thompson, R. A. (2002). Mother-child conflict in the toddler years: Lessons in emotion, morality, and relationships. Child development, 73(4), 1187-1203.

Laibe, D., Carlo, G., Torquati, J., and Ontai, L. (2004). Children's perception of family relationships as assessed in doll story comletion task: Links to parenting, social competence, and externalizing behavior. Social Development, 13(4), 551-569.

Mcbride, B.A., Schoppe, S.J., and Rane, T.R. (2002). Child characteristics, parenting stress, and parental involvement: fathers versus mothers. Journal of Marriage and Family, 64, 998-1011.

Özyürek, A., Şahin, F.T. (2005). 5 ve 6 yaş grubunda çocuğu olan ebeveynlerin tutumlarının incelenmesi. Gazi Üniversitesi Gazi Eğitim Fakültesi Dergisi, 25(2), 19-34.

Özdemir, A.D. (2012). Bazı değişkenler açısından okul öncesi dönemdeki çocukların sosyal becerilerinin ve ailelerinin ebeveynliğe yönelik tutumları. Doktora Tezi, Selçuk Üniversitesi, Konya. 
Paley, B., Conger, R.D., and Harold, G.T. (2000). Parent's affect adolescent cognitive representations and adolescent social development. Journal of Marriage and Family, 62, 761-776.

Salı, G. (2014). Okulöncesi dönem çocuklarında akran ilişkilerinin ve akran şiddetine maruz kalmanın çeşitli değişkenler açısından incelenmesi. Çukurova Üniversitesi Ĕ̆itim Fakültesi Dergisi, 43(2),195-216.

Saygı, D. (2011). Ebeveyn- çocuk ilişkisi ölçeğinin Türkçeye uyarlanması ve anne- çocuk ilişkisinin bazı değişkenler açısından incelenmesi: İstanbul örneklemi. Yüksek Lisans Tezi, Marmara Üniversitesi, İstanbul.

Schneider, B.H., Atkinson, L., and Tardif, C. (2001). Child-parent attachment and children's peer relations: A quantitative review. Developmental Psychology. 37(1), 86-100.

Spinrad, T. L., Eisenberg, N., Gaertner, B., Popp, T., Smith, C. L., Kupfer, A., Greving, K., Liew, J., and Hofer, C. (2007). Relations of maternal socialization and toddlers' effortful control to children's adjustment and social competence. Developmental Psychology, 43(5), 1170-1186.

Şendil, G. (2014). Ebeveyn Çatışmasının Çocuklar Üzerindeki Etkisi. Ankara: Nobel Yayıncılık.

Şendoğdu, M.C. (2000). Anaokuluna devam eden 5-6 yaş çocuklarının anne babalarını algılamaları ile anne babaların kendi tutumlarını algılamaları arasındaki ilişki. Yüksek Lisans Tezi, Gazi Üniversitesi, Ankara.

Tezel Şahin, F., Özyürek, A. (2008). 5-6 yaş grubu çocuğa sahip ebeveynlerin özelliklerinin çocuk yetiştirme tutumlarına etkisinin incelenmesi. Türk Eğitim Bilimleri Dergisi, 6(3), 395-414.

Tabachnick, B.G., Fidell, L.S. (2013). Using Multivariate Statistics. sixth ed. Boston: Pearson.

Tarkoçin, S. (2014). Okul öncesi eğitim kurumuna devam eden 48-66 aylık çocukları olan ebeveynlerin çocukları ile iletişim kurma düzeyleri ve davranış sorunları arasındaki ilişkinin incelenmesi. Yüksek Lisans Tezi, Marmara Üniversitesi, İstanbul.

Tayan, E., Gedik, S. D., Morkoyunlu, Z., Sözbilir, M., Konyalioğlu, A. C. (2019). Ebeveyn-Çocuk İlişkisi Konulu Makaleler: Tematik İçerik Analizi Çalışması. Eskişehir Osmangazi Üniversitesi Sosyal Bilimler Dergisi, 20, 1183-1208.

Trawick Smith, J. (2014). Erken Çocukluk Döneminde Gelişim (Çok Kültürlü Bir Bakış Açısı). Akman B, çev. 5. basım. Ankara: Nobel Akademik Yayıncılık.

Uluyurt, F. (2012). Bazı değişkenlere göre okul öncesi eğitim kurumlarına devam eden 5-6 yaş grubu çocuklarının akran ilişkileri, Yüksek Lisans Tezi, Selçuk Üniversitesi, Konya.

Üstünöz, A., Güvenç, G., Akyüz, A., and Oflaz, F. (2010). Comparison of maternal- and paternalfetal attachment in Turkish couples. Midwifery, 26,1-9.

Yavuzer, H. (2016). Ana- Baba ve Çocuk. 26. Basım. İstanbul: Remzi Kitabevi.

Yavuzer, H. (2014). Çocuk Psikolojisi. 37. Basım. İstanbul: Remzi Kitabevi.

Yaşar, M. (2015). Okul öncesi dönemde sosyal-duygusal gelişim. Metin, E.N., Turan, F., Yükselen, A.İ., editörler. Her Yönüyle Okul Öncesi Eğitim -1-. 2. basım. Ankara: Hedef CS Basın Yayın.

Yener, P. (2015). Okul öncesi eğitimi alan 60 ay ve üzeri çocukların sosyal beceri düzeyleri ile annelerinin çocuk yetiştirme tutumları arasındaki ilişkinin incelenmesi, Yüksek Lisans Tezi, Gazi Üniversitesi, Ankara.

Yörükoğlu, A. (2000). Çocuk Ruh Sağhlğı. 24. basım. İstanbul: Özgür Yayıncilık. 
Yüksek Usta, S. (2014). Okul öncesi dönem çocuklarda davranış problemlerinin anne-çocuk ve öğretmen çocuk ilişkileri açısından incelenmesi, Yüksek Lisans Tezi, Hacettepe Üniversitesi, Ankara.

Zhang, X., and Chen, H. (2010). Reciprocal influences between parents' perceptions of mother-child and father-child relatipnships: A short-term longitudinal study in Chinese preschoolers. The Journal of Genetic Psychology, 171(1), 22-34.

Zhang, X. (2011). Parent-child and teacher-child relationships in Chinese preschoolers: The moderating role of preschool experiences and the mediating role of social competence. Early Childhood Research Quarterly, 26(2), 192-204. 